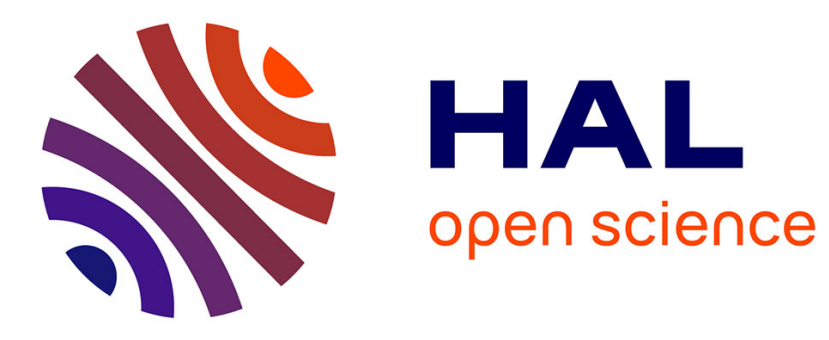

\title{
Fatal Fusobacterium necrophorum infection with gynecological Lemierre's syndrome
}

Barnabé Reymond, Pierre Huette, Pierre-Alexandre Roger, Estelle Tredez,

Odile Gagneur, Sophie Sanguin, Raphaël Guihéneuf, Hervé Dupont, Yazine

Mahjoub, Osama Abou Arab

\section{To cite this version:}

Barnabé Reymond, Pierre Huette, Pierre-Alexandre Roger, Estelle Tredez, Odile Gagneur, et al.. Fatal Fusobacterium necrophorum infection with gynecological Lemierre's syndrome. Médecine et Maladies Infectieuses, 2019, 49, pp.72 - 74. 10.1016/j.medmal.2018.09.006 . hal-03486849

\section{HAL Id: hal-03486849 \\ https://hal.science/hal-03486849}

Submitted on 20 Dec 2021

HAL is a multi-disciplinary open access archive for the deposit and dissemination of scientific research documents, whether they are published or not. The documents may come from teaching and research institutions in France or abroad, or from public or private research centers.
L'archive ouverte pluridisciplinaire HAL, est destinée au dépôt et à la diffusion de documents scientifiques de niveau recherche, publiés ou non, émanant des établissements d'enseignement et de recherche français ou étrangers, des laboratoires publics ou privés.

\section{(ㅇ)(1) $\$$}

Distributed under a Creative Commons Attribution - NonCommercial| 4.0 International 


\section{Fatal Fusobacterium necrophorum infection with gynecological Lemierre's syndrome} Infection fatale à Fusobacterium necrophorum avec syndrome de Lemierre gynécologique

Barnabé Reymond ${ }^{1}$, Pierre Huette ${ }^{2}$, Pierre Alexandre Roger ${ }^{3}$, Estelle Tredez ${ }^{4}$, Odile Gagneur ${ }^{5}$, Sophie Sanguin ${ }^{6}$, Raphael Guiheneuf ${ }^{7}$, Hervé Dupont ${ }^{8}$, Yazine Mahjoub $^{9}$, Osama Abou $\operatorname{Arab}^{10}$

${ }^{1}$ Barnabé Reymond. Pôle d'Anesthésie-Réanimation, CHU Amiens Picardie, 80000 Amiens, France.

2 Pierre Huette. Pôle d'Anesthésie-réanimation, CHU Amiens Picardie, 80000 Amiens, France.

${ }^{3}$ Pierre Alexandre Roger. Pôle d'Anesthésie-Réanimation, CHU Amiens Picardie, 80000 Amiens, France.

${ }^{4}$ Estelle Tredez. Service d'anatomie pathologique. CHU Amiens Picardie, 80000 Amiens, France.

${ }^{5}$ Odile Gagneur. Service de gynécologie-obstétrique. CHU Amiens Picardie, 80000 Amiens, France.

${ }^{6}$ Sophie Sanguin. Service de gynécologie-obstétrique. CHU Amiens Picardie, 80000 Amiens, France.

${ }^{7}$ Raphael Guiheneuf. Service de bactériologie. CHU Amiens Picardie, 80000 Amiens, France.

${ }^{8}$ Hervé Dupont. Pôle d'Anesthésie-réanimation, CHU Amiens Picardie, 80000 Amiens, France.

${ }^{9}$ Yazine Mahjoub. Pôle d'Anesthésie-réanimation, CHU Amiens Picardie, 80000 Amiens, France.

${ }^{10}$ Osama Abou Arab. Pôle d'Anesthésie-réanimation, CHU Amiens Picardie, 80000 Amiens, France.

\section{Corresponding author}

Pierre HUETTE, Département d'Anesthésie-Réanimation, CHU d'Amiens Picardie, F-80054 Amiens, France; e-mail: huette.pierre@chu-amiens.fr, phone number: +33 649851754.

Keywords: Fusobacterium necrophorum, Lemierre's syndrome, gynecological infection 
Mots clés : Fusobacterium necrophorum, syndrome de Lemierre, infection gynécologique 
A 22-year-old woman with no medical history was admitted to the emergency department of a primary care hospital with a flu-like syndrome after several days of selfmedication with ibuprofen.

On examination the patient complained of asthenia and dyspnea. The pulmonary examination revealed a productive cough. Her temperature on admission was $38.2^{\circ} \mathrm{C}$. Laboratory findings revealed acute kidney failure (creatinine clearance: $13 \mathrm{~mL} / \mathrm{min}$ estimated by MDRD formula), acute liver failure, and elevated serum lactate level of $6 \mathrm{mmol} / \mathrm{L}$. Blood specimens were collected for culture. The patient was transferred to the tertiary care hospital of Amiens for admission to the intensive care unit because of signs of severe sepsis.

On arrival the patient's clinical presentation had deteriorated with respiratory distress and severe dyspnea. Her respiratory rate was high and nasal oxygen was increased to $6 \mathrm{~L} / \mathrm{min}$. The chest examination revealed small non-necrotic purpuric lesions. The gynecological examination revealed suspicious leukorrhea and vaginal edema with no intrauterine device. Laboratory tests indicated a white blood cell count of $23,000 / \mathrm{mm}^{3}$, a platelet count of $11,000 / \mathrm{mm}^{3}$, anemia (hemoglobin $10 \mathrm{~g} / \mathrm{dL}$ ), C-reactive protein at $320 \mathrm{mg} / \mathrm{L}$, severe acute kidney failure (creatinine clearance $13 \mathrm{~mL} / \mathrm{min}$, serum creatinine $398 \mu \mathrm{mol} / \mathrm{L}$, and serum urea $25.7 \mathrm{mmol} / \mathrm{L}$ ), severe liver failure (serum bilirubin $65 \mu \mathrm{mol} / \mathrm{L}$, prothrombin time 43\%) with no signs of hemolytic anemia (schizocytes $1 \%$, serum haptoglobin $1.78 \mathrm{~g} / \mathrm{L}$ ). The chestabdomen-pelvis computed tomography revealed multiple alveolar consolidations and a pericervical, uterine, and pelvic collection without air bubbles. Fluid therapy, oseltamivir, and empirical antibiotic therapy with cefotaxime/rovamycine for community-acquired pneumonia and/or severe flu were initiated. Despite treatment, the patient developed hypotension within the following hour which was refractory to repeated fluid challenges 
leading to the administration of high-dose norepinephrine and orotracheal intubation with mechanical ventilation. A renal replacement therapy was initiated due to lactic acidosis. Gynecological referral and a more thorough examination did not reveal any clinical induration of the abscess. Blood cultures yielded Gram-negative bacteria without identification. A broad-spectrum antibiotic therapy was administered with piperacillintazobactam, amikacin, and clindamycin. Laboratory tests for macrophage activation syndrome were performed, but without any significant results (ASAT: $82 \mathrm{IU} / \mathrm{L}$, ALAT: $30 \mathrm{IU} / \mathrm{L}$, serum ferritin: $2,570 \mathrm{ng} / \mathrm{L}$, serum triglycerides: $1.91 \mathrm{~g} / \mathrm{L})$.

The patient's clinical status deteriorated with the administration of norepinephrine at $2.8 \mu \mathrm{g} / \mathrm{kg} / \mathrm{min}$ associated with increased serum lactate levels and refractory arterial hypotension and poor tissue perfusion. Despite the presence of clinical induration, a vaginal biopsy was performed. The histological examination revealed a non-specific inflammation with polymorphonuclear cell infiltration without any abscess nor necrosis. Surgery was suggested but with an unfavorable benefit/risk ratio: no collection observed on CT scan, refractory shock with high-dose vasoactive drug administration, and laboratory signs of coagulopathy secondary to sepsis. The patient developed sepsis with multiple organ dysfunction syndrome 36 hours after admission and died.

An autopsy was performed the following day and revealed suppurative alveolitis with multiple infarctions and thrombophlebitis, bilateral pleurisy, shock liver, signs of macrophage activation syndrome, and congestive spleen. The examination of the pelvis revealed necrosis of the vaginal wall and cervix, and abscesses with suppurative thrombophlebitis of the pelvic, periuterine, and perivesical adipose tissues (Figure 1). The pre-mortem bacteriological examination identified Fusobacterium necrophorum in bronchoalveolar lavage culture, blood culture, and vaginal biopsy. Antimicrobial 
susceptibility testing showed susceptibility to amoxicillin, cefotaxime, and metronidazole, intermediate susceptibility to rifampicin, and resistance to vancomycin.

\section{Discussion}

Many reports of $F$. necrophorum have been published in the literature, but few focused on gynecological infections (Table 1). F. necrophorum is a commensal bacterium of the gastrointestinal tract commonly responsible for pharyngitis. It is also found in the oral cavity and vagina. It is known to induce soft tissue infection with abscess formation, subsequently resulting in septic thrombophlebitis. The combination of internal jugular vein thrombophlebitis and pharyngitis is known as Lemierre's syndrome (Lemierre reported the first cases in 1936) [1].

Our case report is a gynecological case of Lemierre's syndrome. The patient's clinical presentation was initially confusing as she presented with respiratory symptoms associated with a flu-like syndrome in a seasonal context of influenza epidemic. She did not complain of any gynecological symptoms. The gynecological examination revealed early signs of edema. However, her primary symptoms suggested respiratory failure. The self-medication with ibuprofen may have worsened the clinical presentation. Our diagnosis of severe pneumonia and/or influenza had to be revised as the patient developed refractory severe septic shock several hours after admission, which is quite unusual considering her young age and the absence of history of immunosuppression. Further investigations were performed following the extension of the vaginal edema after the first day of admission. Several gynecological examinations did not find any intrauterine device. The pelvic CT scan revealed a soft tissue infiltration, but no organized collection justifying surgery, especially in the presence of uncontrolled circulatory failure and sepsis-induced coagulopathy. 
The microbiological identification was not difficult. Blood culture, bronchoalveolar lavage, and vaginal secretions were all positive for F. necrophorum. F. necrophorum is an anaerobic filament-forming Gram-negative bacillus [2].

The pathogenesis is associated with leukotoxin production. The inoculation of virulent toxin-producing strains induces thrombosis [3]. The antibiotic therapy consisted of cefotaxime adapted to the results of the antimicrobial susceptibility test. No standard therapy has ever been established. Many case reports were associated with successful outcome with metronidazole (500 mg every 8 hours) and ceftriaxone ( 2 g every 24 hours) [1]. As some strains may produce beta-lactamases, the use of penicillin should be combined with a beta-lactamase inhibitor [4]. Drainage of fluid collections and/or debridement of necrotic tissue are necessary. Due to the unusual clinical presentation of our patient, surgery was proposed too late at the stage of multiple organ failure. The autopsy confirmed the pulmonary involvement with multiple lung and pleural abscesses. A hematogenous spread seemed possible as blood cultures were positive, and the autopsy revealed secondary lung abscesses and uterine and lung phlebitis.

No standard therapy has ever been established. Only case reports or small series have been published in the literature. An indexed search on PubMed using "fusobacterium" [mesh] AND "gynecologic disease" identified seven cases $[5,6,7,8,9,10]$ in women aged between 15 and 47 years. The gynecological presentations varied with a history of uterine tube infection, rectal or bladder fistula, or secondary hepatic or mesenteric abscesses. One death was reported among these published case reports. Surgery combined with a threedrug antibiotic therapy was suggested, usually including third-generation cephalosporin, metronidazole, and beta-lactam antibiotics. 


\section{Conclusion}

Gynecological Lemierre's syndrome may induce septic shock and pulmonary infections.

This rare diagnosis must be kept in mind. Treatment is based on an emergency antibiotic therapy with metronidazole and cephalosporin, curative anticoagulation, and surgery.

\section{Declaration of interests}

The authors declare no competing interest.

\section{Funding source}

None

\section{Ethical approval}

Not required 


\section{References}

1. Armstrong null, Spooner null, Sanders null: Lemierre's Syndrome. Curr Infect Dis Rep $2000 ; 2: 168-173$

2. Hagelskjaer Kristensen L, Prag J: Human necrobacillosis, with emphasis on Lemierre's syndrome. Clin Infect Dis Off Publ Infect Dis Soc Am 2000; 31:524-532

3. Kanoe $M$, Yamanaka $M$, Inoue $M$ : Effects of Fusobacterium necrophorum on the mesenteric microcirculation of guinea pigs. Med Microbiol Immunol (Berl) 1989; 178:99-104

4. Brook I: Infections caused by beta-lactamase-producing Fusobacterium spp. in children. Pediatr Infect Dis J 1993; 12:532-533

5. Huynh-Moynot S, Commandeur D, Danguy des Déserts $M$, et al.: [Septic shock Fusobacterium necrophorum from origin gynecological at complicated an acute respiratory distress syndrome: a variant of Lemierre's syndrome]. Ann Biol Clin (Paris) 2011; 69:202-207

6. Klare P, Buchmann E: [Multiple liver abscesses in long-term intrauterine device]. Zentralbl Gynakol 1996; 118:530-532

7. Baker DA: Vesicouterine fistula caused by Fusobacterium necrophorum. J Infect Dis $1982 ; 145: 282$

8. Pol H, Guerby P, Duazo Cassin L, et al.: Dangerous Liaisons: Pelvic Variant of Lemierre Syndrome by Right Common Iliac Vein Thrombophlebitis After Sexual Intercourse. J Low Genit Tract Dis 2017; 21:e37-e39

9. Hedengran KK, Hertz J: Lemierre's syndrome after evacuation of the uterus: a case report. Clin Case Rep 2014; 2:60-61

10. Treszezamsky AD, Molina Boero MF, Mehta I: Cervical conization complicated by sepsis with lung and liver abscesses. J Low Genit Tract Dis 2010; 14:130-133 
Figure 1. A/ Multifocal abscessed necrosis with suppurative thrombophlebitis of the vaginal wall, cervix. B/ Necrotic areas with suppressed venous thrombosis with bacterial cluster.

Figure 1. A/ Nécrose abcédée plurifocale avec thrombophlébite suppurée de la paroi vaginale et du col de l'utérus. B / Plages nécrotiques avec thrombose veineuse suppurée avec amas de germes.

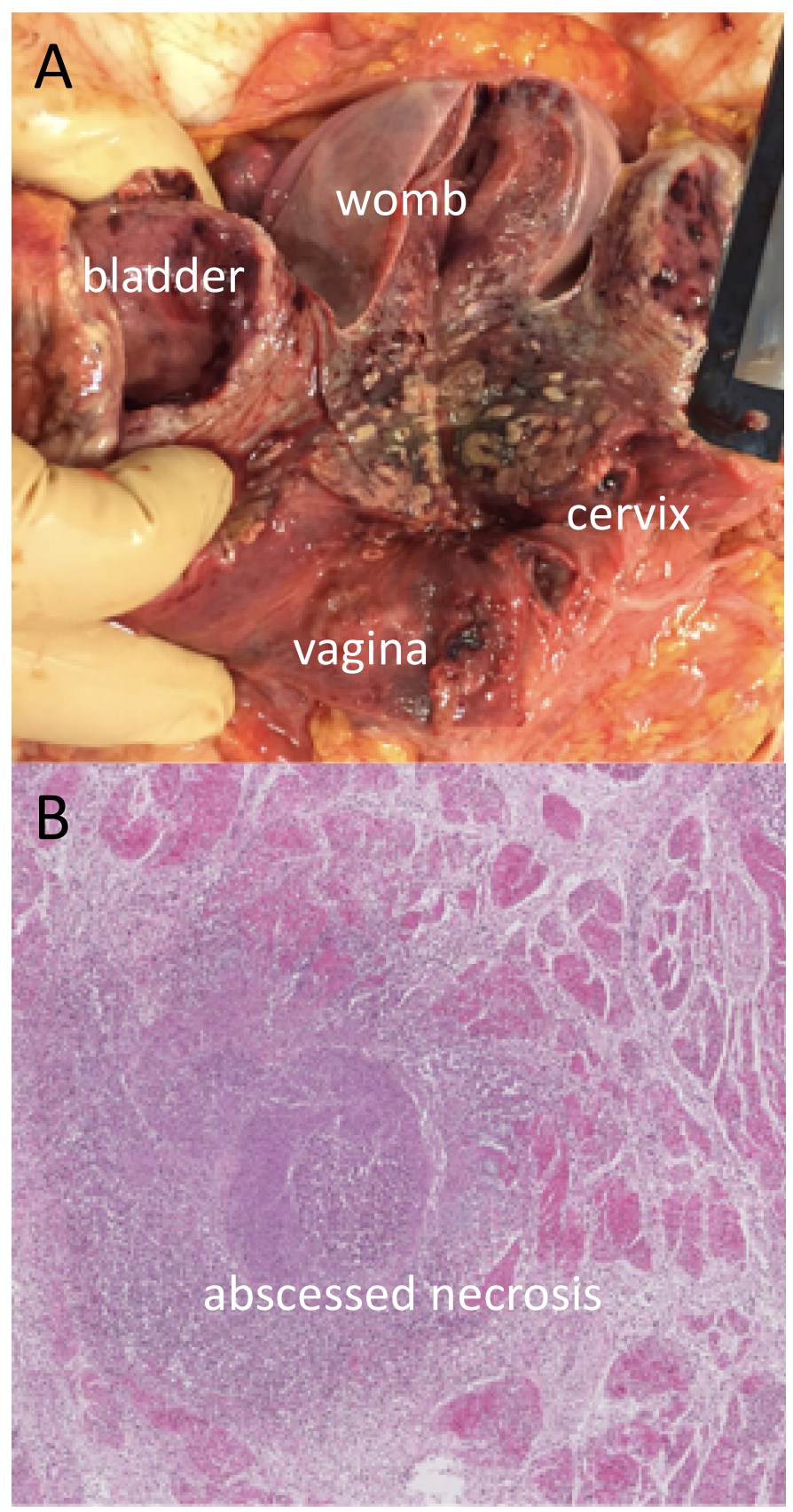


Table 1. Review of seven cases of gynecological Lemierre's syndrome

Tableau 1. Revue de la littérature : sept cas de syndrome de Lemierre

\begin{tabular}{|c|c|c|c|c|c|c|}
\hline $\begin{array}{c}\text { Case } \\
\text { number }\end{array}$ & Ref & $\begin{array}{c}\text { Age } \\
\text { (year) }\end{array}$ & $\begin{array}{c}\text { Infection } \\
\text { source }\end{array}$ & $\begin{array}{c}\text { Secondary } \\
\text { sites }\end{array}$ & Thrombosis & Outcome \\
\hline 1 & {$[4]$} & 47 & IUD & Lung & $\begin{array}{c}\text { Left ovarian } \\
\text { vein }\end{array}$ & Survival \\
\hline 2 & {$[5]$} & 35 & IUD & Liver & NA & Survival \\
\hline 3 & {$[6]$} & NA & Uterus & Bladder & NA & NA \\
\hline 4 & {$[7]$} & NA & IUD & $\begin{array}{c}\text { Fallopian } \\
\text { tubes }\end{array}$ & Death \\
\hline 5 & {$[8]$} & 15 & Vagina & Lung & common & Survival \\
\hline 7 & {$[10]$} & 44 & Cervix & Pleura, & Internal \\
lung, liver & jugular vein & Survival \\
\hline 6 & {$[9]$} & 26 & Uterus & Lung, liver & $\begin{array}{c}\text { Internal } \\
\text { jugular vein }\end{array}$ & Survival \\
\hline
\end{tabular}

IUD: intrauterine device; NA: non-available 